\title{
Proton Nuclear Magnetic Resonance Spectrometric and Spectrophotometric Studies on Hydrophobic and Electrostatic Interactions of Cationic Water- Soluble Porphyrin with Nucleotides
}

\author{
Masaaki Tabata $†$, Makoto SaKaI, Katumi Yoshioka and Hiroaki Kodama \\ Department of Chemistry, Faculty of Science and Engineering, Saga University, Saga 840, Japan
}

\begin{abstract}
The interactions of cationic porphyrin, tetrakis(4- $N$-methylpyridyl)porphine $\left(\mathrm{H}_{2} \mathrm{TMPyP}\right)$, with 5 '-adenosine triphosphate (ATP), 5'-adenosine diphosphate (ADP), 5'-adenosine monophosphate (AMP), adenosine (A), adenine (AN) and metal complexes of ATP were evaluated by UV-VIS and ' $\mathrm{H}-\mathrm{NMR}$ spectroscopy at $25^{\circ} \mathrm{C}$ and an ionic strength of $0.1 \mathrm{~mol} \mathrm{dm}^{-3}$ $\left(\mathrm{NaNO}_{3}\right)$. The formation constants $\left(\log K / \mathrm{mol}^{-1} \mathrm{dm}^{3}\right)$, defined as $\mathrm{L}+\mathrm{H}_{2} \mathrm{TMPyP} \rightleftharpoons \mathrm{L}\left(\mathrm{H}_{2} \mathrm{TMPyP}\right)$, were found to be 2.92 $\pm 0.06,2.92 \pm 0.16,2.59 \pm 0.07,2.20 \pm 0.07,2.10 \pm 0.09,2.83 \pm 0.03,2.93 \pm 0.04$ and $2.80 \pm 0.07$ for L $=\mathrm{ATP}^{4-}, \mathrm{ADP}^{3-}$, $\mathrm{AMP}^{2-}, \mathrm{A}, \mathrm{AN}, \mathrm{Mg}(\mathrm{ATP})^{-2}, \mathrm{Ca}(\mathrm{ATP})^{2-}$ and $\mathrm{Ni}(\mathrm{ATP})^{2-}$, respectively. The binding of magnesium(II), calcium(II) or nickel(II) to ATP does not affect the formation of the molecular complex of $\mathrm{H}_{2}$ TMPyP with ATP. The addition of ethanol or the protonation of an adenine base, however, destabilizes the molecular complex. The predominant factor (75\%) for stabilization of the molecular complex is a hydrophobic interaction between the porphyrin plane and the adenine base; the remaining factor $(25 \%)$ is an electrostatic interaction between the negatively charged phosphates of nucleotides and the positively charged $N$-methylpyridyl groups of $\mathrm{H}_{2}$ TMPyP. A hydrophobic interaction was also confirmed by 2-D ${ }^{1} \mathrm{H}-\mathrm{NMR}$ experiments, in which large upfield shifts were observed for the chemical shifts of $\mathrm{H}-2$ and H-8 protons of adenine base, and $\mathrm{H}-\mathbf{l}^{\prime}$ of ribose.
\end{abstract}

Keywords Molecular complex, porphyrin, nucleotides, hydrophobic interaction, electrostatic interaction

Studies concerning the interaction of porphyrins or metalloporphyrins with DNA or RNA have revealed important features of the structure and dynamics of polynucleic acids. Both the size and charge of groups on the periphery of porphyrins and the axial-ligation of metalloporphyrins determine the binding sites as well as the modes of the polynucleotides. ${ }^{1}$ Furthermore, because of the selective accumulation of porphyrins in tumors and the use of porphyrins in both diagnosis and photodynamic treatment of cancer, the interaction of porphyrins with tumor cells is very important.

Porphyrins generally interact with DNA or RNA through two modes: (1) an intercalation of porphyrin into base-pairs of DNA at GC sites, and (2) an electrostatic interaction of positively charged $\mathrm{N}$-methyl groups in porphyrin with phosphate groups in DNA. ${ }^{1-3}$ Electrostatic interactions are further divided into two modes: non-selective electrostatic associations with phosphate groups and structurally specific interactions in AT-rich regions of DNA.4-7 Further compelling evidence regarding the above types of binding forms has recently been presented concerning equilibrium, kinetic and NMR studies. ${ }^{8,9}$ Other types of binding, including intercalation at mixed GC/AT sites, may

† To whom correspondence should be addressed. occur. Our final goal is to elucidate the mechanism of the interaction of DNA with porphyrin and to analyze the DNA composition in tumor cells by using porphyrin. However, the relative selectivity of GC vs. AT binding and the nature of charge interactions between porphyrins and DNA have not been fully understood.

Considering the complexity of the interactions of porphyrins and metalloporphyrins with DNA, it is useful to employ a simple model system to establish some details concerning the interactions. A few papers have been reported regarding molecular complexes of porphyrin and nucleotides studied by NMR and X-ray procedures. ${ }^{10,11}$

The present paper describes the results assessing the interactions of a cationic-free base porphyrin, tetrakis(4- $\mathrm{N}$-methylpyridyl)porphine $\left(\mathrm{H}_{2} \mathrm{TMPyP}\right)$, with $5^{\prime}$ adenosine triphosphate (ATP), 5'-adenosine diphosphate (ADP), 5'-adenosine monophosphate (AMP), adenosine (A), adenine (AN), $\mathrm{Mg}(\mathrm{ATP}), \mathrm{Ca}(\mathrm{ATP})$ and $\mathrm{Ni}(\mathrm{ATP})$ in terms of UV-VIS and ${ }^{1} \mathrm{H}-\mathrm{NMR}$ spectroscopy. The dependence of the formation constants on the charge of nucleotides, bound metals, ethanol and $\mathrm{pH}$ was studied in order to elucidate the characteristics of the interaction between the nucleotides and the porphyrin. This study suggests that the porphyrin interacts with nucleotides through both hydrophobic and electrostatic inter- 
actions. The porphyrin plane binds to the adenine base by a hydrophobic interaction; in addition, the cationic group of the porphyrin binds to phosphate groups by an electrostatic interaction. The hydrophobic interaction contributes to the binding of $\mathrm{H}_{2}$ TMPyP and the nucleotides to a degree of $75 \%$; the remaining contribution $(25 \%)$ involves an electrostatic interaction. Metal ions bound to phosphate groups do not affect the formation of molecular complexes; rather, the protonation of an adenine base or the addition of ethanol destroys molecular complexes.

\section{Experimental}

Tetrakis(4- $N$-methylpyridyl)porphine was purchased as an tosylate salt from DOJINDO Laboratory, Kumamoto, Japan, and converted to its nitrate form by passing it through an anionic-exchange resin, since tosylate interacts with $\mathrm{H}_{2}$ TMPyP in high concentrations. Nucleotides, adenosine and adenine were purchased from Sigma Chemicals Co. The concentrations of magnesium, calcium and nickel nitrates in stock solutions were determined complexometrically. Other stock solutions were prepared by weighing the reagents. All reagents were of analytical reagent grade.

The formation constants of the molecular complexes were determined at pH 7.0 in an $N, N^{\prime}$-bis(2-sulfonatoethyl)-piperazine (PIPES) buffer at $25^{\circ} \mathrm{C}$. The ionic strength was adjusted to $0.1 \mathrm{~mol} \mathrm{dm}^{-3}$ by metal nitrates $\left(\mathrm{NaNO}_{3}\right.$ and $\mathrm{M}\left(\mathrm{NO}_{3}\right)_{2}, \mathrm{M}=\mathrm{Mg}^{2+}, \mathrm{Ca}^{2+}$ and $\mathrm{Ni}^{2+}$ ). The absorption spectra were recorded using a Jasco UVIDEC 610-C spectrophotometer in a $1-\mathrm{cm}$ cell with a thermostated water jacket. The $\mathrm{pH}$ values were determined by a Radiometer Ion 85 Ion Analyzer with a combined electrode (GK2401 B). A $1.000 \times 10^{-2} \mathrm{~mol} \mathrm{dm}^{-3}$ nitric acid solution containing $0.09 \mathrm{~mol} \mathrm{dm}^{-3}$ sodium nitrate was employed at a standard hydrogen ion concentration $\left(-\log \left[\mathrm{H}^{+}\right]=2.000\right)$. The ${ }^{1} \mathrm{H}-\mathrm{NMR}$ spectra were recorded on a JEOL GX-270 spectrophotometer (270 MHz) at $25^{\circ} \mathrm{C}$ in a $\mathrm{D}_{2} \mathrm{O}$ solvent, using the center peak of the tetramethylammonium ion as an internal reference. All chemical shifts were converted to a sodium 3-(trimethylsilyl)-1-propanesulfonate (DSS) reference gives unreliable chemical shifts, since the ${ }^{1}$ H-NMR signals of the trimethylsilyl group shift considerably due to a hydrophobic interaction of DSS with the aromatic moiety of ligands. ${ }^{12}$ A routine Fourier-transfer program was used to analyze the ${ }^{1} \mathrm{H}-\mathrm{NMR}$ spectra, and ${ }^{1} \mathrm{H}-\mathrm{NMR}$ signals were accumulated more than 100 times. The chemical shifts were assigned using a 2-D ${ }^{1} \mathrm{H}-\mathrm{NMR}$ method.

\section{Results}

Formation of molecular complexes of $\mathrm{H}_{2} T M P y P$ with nucleotides

The formation constants of the molecular complexes of $\mathrm{H}_{2}$ TMPyP with nucleotides were determined spectro- photometrically. The absorption spectrum of $\mathrm{H}_{2}$ TMPyP changed considerably in the presence of nucleotides. The absorbance at $423 \mathrm{~nm}$ (the absorption maximum of free-base $\mathrm{H}_{2}$ TMPyP) decreased with increasing the nucleotide; the absorption maximum wavelength shifted to a longer wavelength of about $10 \mathrm{~nm}$. Similar absorption spectra have been observed in the reaction of $\mathrm{H}_{2}$ TMPyP with DNA. ${ }^{4}$ Under the present experimental conditions ( $\mathrm{pH} 7.0$ ) porphyrin is in its free-base form, since the protonation constant of $\mathrm{H}_{2}$ TMPyP to form $\mathrm{H}_{3} \mathrm{TMPyP}$ is $10^{1.4} .^{13}$ The reaction of $\mathrm{H}_{2} \mathrm{TMPyP}$ with nucleotides (L) can thus be given by

$$
n \mathrm{~L}+\mathrm{H}_{2} \mathrm{TMPyP} \stackrel{K}{\rightleftharpoons} \mathrm{L}_{n}\left(\mathrm{H}_{2} \mathrm{TMPyP}\right)
$$

the equilibrium constant is defined by

$$
K=\left[\mathrm{L}_{n}\left(\mathrm{H}_{2} \mathrm{TMPyP}\right)\right][\mathrm{L}]^{-n}\left[\mathrm{H}_{2} \mathrm{TMPyP}^{-1}\right. \text {. }
$$

Equation (2) can be rearranged in logarithmic form as

$$
\begin{aligned}
\log K= & \log \left\{\left[\mathrm{L}_{n}\left(\mathrm{H}_{2} \mathrm{TMPyP}\right)\right] /\left[\mathrm{H}_{2} \mathrm{TMPyP}\right]\right\} \\
& -n \log [\mathrm{L}] .
\end{aligned}
$$

The first term in the right-hand side of Eq. (3) was determined from the absorbances in the various concentrations of nucleotides, and is plotted against the concentrations of nucleotides in Fig. 1. This plot gives a straight line with a slope of unity $(n=1)$, and shows that one molecule of the nucleotide reacts with $\mathrm{H}_{2}$ TMPyP. Because of the limitation of the solubility of nucleotides, the formation of a molecular complex in which two molecules of the nucleotides are bound to one molecule of $\mathrm{H}_{2}$ TMPyP was not observed under the present experimental conditions. The formation con-



Fig. 1 Plot of $\log \left\{\left(\mathrm{L}_{n}\left(\mathrm{H}_{2} \mathrm{TMPyP}\right)\right] /\left[\mathrm{H}_{2} \mathrm{TMPyP}\right]\right\}$ vs. $\log [\mathrm{L}] /$ mol d ${ }^{-3}$ in the reactions of $\mathrm{H}_{2}$ TMPyP with ATP $(O)$, AMP (O) and adenosine ( $\square$ ) at $25^{\circ} \mathrm{C}$ and $I=0.1 \mathrm{~mol} \mathrm{dm}^{-3}$ $\left(\mathrm{NaNO}_{3}\right) . \quad C_{\mathrm{H} 2 \mathrm{TMPyP}}=4.09 \times 10^{-6} \mathrm{~mol} \mathrm{dm}^{-3}$ and $\mathrm{pH}=8.90$. 
Table 1 Formation constants of molecular complexes of some nucleotides with $\mathrm{H}_{2} \mathrm{TMPyP}$ at $25^{\circ} \mathrm{C}$ and $I=0.1$ $\mathrm{mol} \mathrm{dm} \mathrm{m}^{-3}\left(\mathrm{NaNO}_{3}\right)$

\begin{tabular}{|c|c|c|c|}
\hline Nucleotides & $\begin{array}{c}\log (K / \\
\left.\mathrm{mol}^{-1} \mathrm{dm}^{3}\right)\end{array}$ & $\begin{array}{l}\text { Electrostatic } \\
\text { interaction, \% }\end{array}$ & $\begin{array}{l}\text { Hydrophobic } \\
\text { interaction, } \%\end{array}$ \\
\hline ATP $^{4-}$ & $2.92 \pm 0.06$ & 25 & 75 \\
\hline ADP $^{3-}$ & $2.92 \pm 0.16$ & 25 & 75 \\
\hline $\mathrm{AMP}^{2-}$ & $2.59 \pm 0.07$ & 15 & 85 \\
\hline Adenosine & $2.20 \pm 0.07$ & - & - \\
\hline Adenine & $2.10 \pm 0.09$ & - & - \\
\hline $\operatorname{Mg}(\text { ATP })^{2-}$ & $2.83 \pm 0.03$ & 22 & 78 \\
\hline $\mathrm{Ca}(\mathrm{ATP})^{2-}$ & $2.93 \pm 0.04$ & 25 & 75 \\
\hline $\mathrm{Ni}(\text { ATP })^{2-}$ & $2.80 \pm 0.07$ & 21 & 79 \\
\hline
\end{tabular}

Contributions of electrostatic and hydrophobic interactions to molecular complex formation were calculated in terms of the difference between the formation constants of the molecular complexes of nucleotides and that of adenosine (see Eq. (4)).

stants of molecular complexes were determined from Eq. (3), and are summarized in Table 1 along with values for adenosine and adenine. The formation constants for ATP, ADP and AMP are higher than those for adenosine and adenine.

\section{Effect of metal ions on molecular complex formation}

Nucleotides bind with metal ions mainly through the phosphate groups of the nucleotides. ${ }^{14,15}$ The formation constants of the molecular complexes were determined in the presence of a large excess $\left(10^{-2} \mathrm{~mol} \mathrm{dm}^{-3}\right)$ of magnesium, calcium or nickel. Under the present experimental conditions, the metal ions are quantitatively bound to $\mathrm{ATP}^{4-}{ }^{16}$ and do not react with freebase $\mathrm{H}_{2} \mathrm{TMPyP}$, both thermodynamically and kinetically. The results are given in Table 1 . These formation constants are comparable to those of free ATP unbound of metals.

\section{Effect of $\mathrm{pH}$ on the formation of molecular complexes}

Nucleotides (ATP, ADP, AMP) protonate at their phosphate groups and the adenine bases at pHs 6.5 and 4 , respectively. ${ }^{17,18}$ The absorption spectra of the molecular complexes were measured in a $\mathrm{pH}$ range 3 10 , and the absorbances at $423 \mathrm{~nm}\left(\lambda_{\max }\right.$ of $\left.\mathrm{H}_{2} \mathrm{TMPyP}\right)$ are plotted against pH (Fig. 2). The absorbances are constant at pH 5-10, and increase at a pH lower than 5 due to a dissociation of the molecular complex. Since the protonation constants of nucleotides are $10^{6.5}, 10^{6.4}$ and $10^{6.0}$ for $\mathrm{ATP}^{4-}, \mathrm{ADP}^{3-}$ and $\mathrm{AMP}^{2-}$, the chemical species of the nucleotides change at pH 5-10. The absorbances, however, are constant at pH 5-10 (Fig. 2). The results indicate that protonation to the phosphate groups does not affect the formation of a molecular complex. In contrast, molecular complexes begin to dissociate at $\mathrm{pH}<5$ through protonation to the adenine base. The protonation constants to the adenine base are $10^{4.06}, 10^{3.96}$ and $10^{3.86}$ for $\mathrm{HATP}^{3-}, \mathrm{HADP}^{2-}$ and AMP-, respectively. ${ }^{17}$ The protonation of $\mathrm{H}_{2}$ TMPyP is

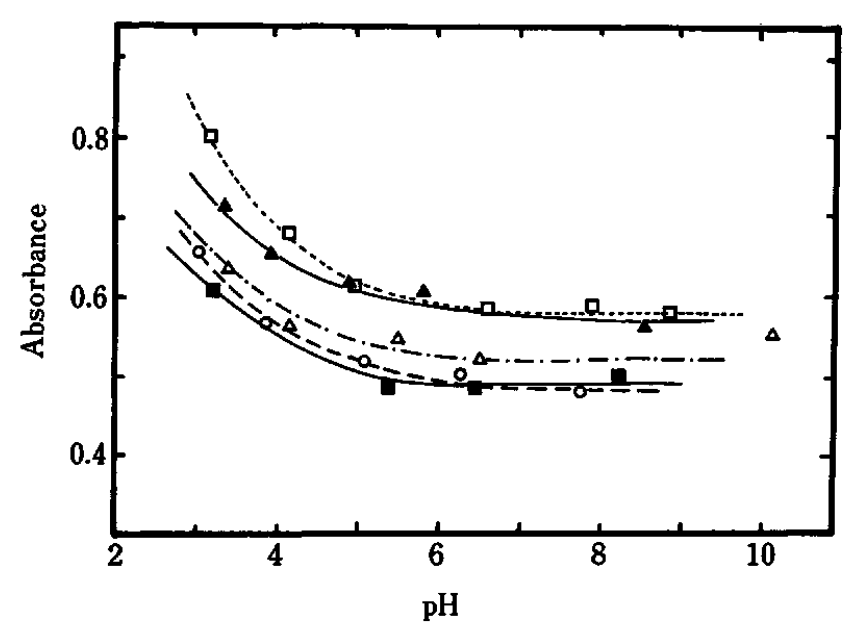

Fig. 2 Effect of $\mathrm{pH}$ on the formation of molecular complexes of $\mathrm{H}_{2}$ TMPyP with ATP $(\square), \operatorname{ADP}(O), \operatorname{AMP}(\Delta)$ and adenosine $(\Delta)$, adenine $(\square)$ at $25^{\circ} \mathrm{C}$ and $I=0.1\left(\mathrm{NaNO}_{3}\right)$. Concentration of $\mathrm{H}_{2} \mathrm{TMPyP}$ is $4.09 \times 10^{-6} \mathrm{~mol} \mathrm{dm}^{-3}$.



Fig. 3 Effect of ethanol on the formation of the molecular complexes of $\mathrm{H}_{2}$ TMPyP with ATP (O) and adenosine (O) at $25^{\circ} \mathrm{C}$ and $I=0.1\left(\mathrm{NaNO}_{3}\right) . C_{\mathrm{H} 2 \mathrm{TMPyP}}=3.97 \times 10^{-6}, C_{\mathrm{ATP}}=$ $5.02 \times 10^{-3}$ and $C_{\text {adenosine }}=1.00 \times 10^{-2},\left(\right.$ unit $\left.=\mathrm{mol} \mathrm{dm}^{-3}\right) . \mathrm{pH}=$ 9.04 for ATP and 8.79 for adenosine.

negligible at $\mathrm{pH} 3-5$; the protonation constant is $10^{1.4} .13$

\section{Effect of ethanol on the formation of molecular complexes}

The addition of ethanol to a solution containing $\mathrm{H}_{2}$ TMPyP and nucleotides increased the absorbance at $423 \mathrm{~nm}$. At a high concentration of ethanol the absorption spectrum was the same as that of $\mathrm{H}_{2}$ TMPyP in the absence of nucleotides. The spectral change indicates a dissociation of the molecular complex by the addition of ethanol. The change in the concentrations of the molecular complexes in various mixed alcoholaqueous solutions is shown in Fig. 3. 
${ }^{\prime} H$-NMR studies of the molecular complexes of $A T P$, $A D P, A M P$ and adenosine with $\mathrm{H}_{2}$ TMPYP.

We used ${ }^{1} \mathrm{H}-\mathrm{NMR}$ to confirm the interaction between $\mathrm{H}_{2}$ TMPyP and nucleotides. Figure 4 illustrates some ${ }^{1} \mathrm{H}-\mathrm{NMR}$ spectra of $\mathrm{H}_{2}$ TMPyP, ATP4- and a mixture of $\mathrm{H}_{2}$ TMPyP and ATP4- in $\mathrm{D}_{2} \mathrm{O}$. The ${ }^{1} \mathrm{H}-\mathrm{NMR}$ spectra of a $10^{-2} \mathrm{~mol} \mathrm{dm}^{-3} \mathrm{H}_{2} \mathrm{TMPyP}$ solution shows two doublets at 8.71 and $9.19 \mathrm{ppm}$ due to the ortho and meta pyridyl protons at $\mathrm{pD} 7.0$. The broad peak between the ortho and meta proton-signals is attributed to the pyrrole protons and is largely due to a slow exchange rate of the tautomerism of the porphyrin imine protons. ${ }^{19}$ The signals for methyl protons of $\mathrm{H}_{2}$ TMPyP were observed at $4.77 \mathrm{ppm}$. The ${ }^{1} \mathrm{H}-\mathrm{NMR}$ signals of $\mathrm{H}-2$ and $\mathrm{H}-8$ protons of adenine and the $\mathrm{H}-\mathrm{I}^{\prime}$ proton of ribose were well characterized at $8.55,8.26$ and $6.14 \mathrm{ppm}$, respectively. Large upfield shifts of these protons were observed for a 1:1 mixture of $\mathrm{H}_{2} \mathrm{TMPyP}$ and ATP. The ${ }^{1} \mathrm{H}-\mathrm{NMR}$ chemical shifts moved to 5.64, 6.38 and $2.58 \mathrm{ppm}$ for the $\mathrm{H}-8, \mathrm{H}-2$ and $\mathrm{H}-\mathrm{1}^{\prime}$ protons, respectively. The upfield shifts of $\mathrm{H}-8$ of adenine and H-1' of ribose were much more pronounced. Furthermore, five signals for ribose protons were well separated from each other in a mixture of ATP and $\mathrm{H}_{2}$ TMPyP (Fig. 4). Especially, the addition of magnesium(II) to the mixture caused the separated signals for ribose protons of $\mathrm{H}-\mathbf{3}^{\prime}$ and $\mathrm{H}-\mathbf{4}^{\prime}$. Similar ' $\mathrm{H}-\mathrm{NMR}$ spectra were also observed for ADP, AMP and adenosine. These signals were assigned by a 2-D ${ }^{~} \mathrm{H}-\mathrm{NMR}$ method; the chemical shifts are summarized in Table 2.

The ${ }^{1} \mathrm{H}-\mathrm{NMR}$ experiments on the $\mathrm{H}_{2} \mathrm{TMPyP} / \mathrm{ATP}$ system directly indicate an interaction between the adenine base and the porphyrin plane. Large upfield shifts of the adenine base protons $(\mathrm{H}-2$ and $\mathrm{H}-8)$ and the $\mathrm{H}-1^{\prime}$ ribose proton suggest a strong hydrophobic interaction of the adenine base with the porphyrin plane.
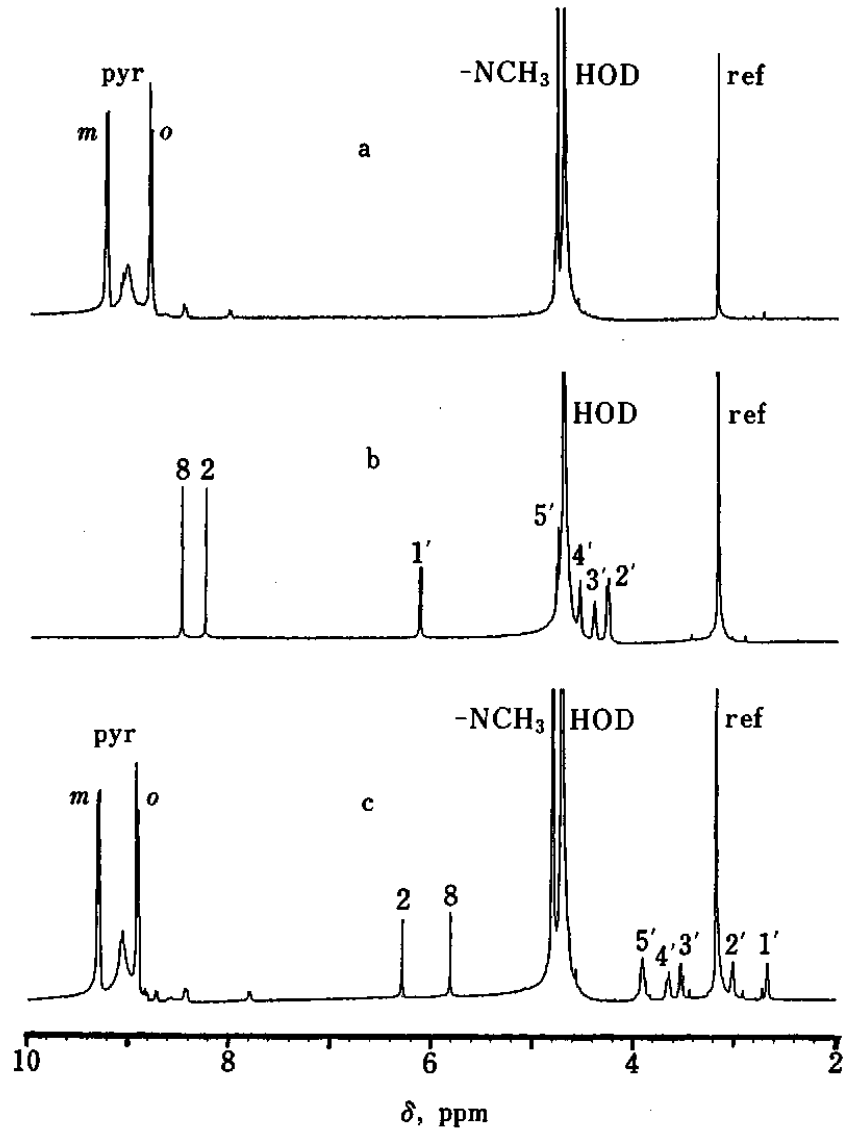

Fig. $4{ }^{1} \mathrm{H}-\mathrm{NMR}$ spectra of $\mathrm{H}_{2}$ TMPyP (a), ATP (b) and 1:1 mixture $\mathrm{H}_{2} \mathrm{TMPyP} / \mathrm{ATP}$ (c) at $\mathrm{pD} 7.0$ in the presence of magnesium $\left(3.33 \times 10^{-2} \mathrm{~mol} \mathrm{dm}^{-3}\right)$. Concentration of $\mathrm{H}_{2} \mathrm{TMPyP}$ is $10^{-2} \mathrm{~mol} \mathrm{dm}^{-3}$. The reference signal is tetramethylammonium; all chemical shifts were converted to a 3-(trimethylsilyl)-1-propanesulfonate (DSS) reference by adding $3.188 \mathrm{ppm}$.

Table 2 Chemical shifts of ${ }^{1} \mathrm{H}-\mathrm{NMR}$ for $\mathrm{H}_{2}$ TMPyP, some nucleotides, $\mathrm{Mg}(\mathrm{ATP})^{2-}$, and the molecular complexes of $\mathrm{H}_{2} \mathrm{TMyP}$ with the nucleotides $\left(25^{\circ} \mathrm{C} ; \mathrm{I}=0.1 ; \mathrm{pD} 7\right.$; concentration of $\left.\mathrm{H}_{2} \mathrm{TMPyP}: 10^{-2} \mathrm{~mol} \mathrm{dm}^{-3}\right)$

\begin{tabular}{|c|c|c|c|c|c|c|}
\hline \multirow{3}{*}{ Sample } & \multicolumn{6}{|c|}{$\delta, \mathrm{ppm}$} \\
\hline & \multicolumn{3}{|c|}{ ATP } & \multicolumn{3}{|c|}{$\mathrm{H}_{2}$ TMPyP } \\
\hline & H-8 & $\mathrm{H}-2$ & $\mathrm{H}-\mathbf{1}^{\prime}$ & $\mathrm{H}-m$ & $\mathrm{H}-\mathrm{o}$ & $\mathrm{H}-\mathrm{NCH}_{3}$ \\
\hline TMPyP & & & & 9.19 & 8.71 & 4.77 \\
\hline ATP & 8.55 & 8.26 & 6.14 & & & \\
\hline $\operatorname{Mg}(\text { ATP })^{2-}$ & 8.50 & 8.26 & 6.14 & & & \\
\hline $\operatorname{ATP} / \mathrm{H}_{2} \mathrm{TMPyP}(1: 1)$ & 5.64 & 6.38 & 2.58 & 9.24 & 8.81 & 4.78 \\
\hline $\mathrm{Mg}(\mathrm{ATP}) / \mathrm{H}_{2} \mathrm{TMPyP}(1: 1)$ & 5.82 & 6.30 & 2.67 & 9.29 & 8.92 & 4.81 \\
\hline ADP & 8.53 & 8.26 & 6.14 & & & \\
\hline $\mathrm{ADP} / \mathrm{H}_{2} \mathrm{TMPyP}(1: 1)$ & 5.65 & 6.34 & 2.47 & 9.26 & 8.84 & a \\
\hline AMP & 8.58 & 8.24 & 6.14 & & & \\
\hline $\mathrm{AMP} / \mathrm{H}_{2} \mathrm{TMPyP}(1: 1)$ & 5.73 & 6.57 & 2.87 & 9.26 & 8.85 & $\mathbf{a}$ \\
\hline Adenosine & 8.32 & 8.21 & 6.06 & & & \\
\hline Adenosine/ $\mathrm{H}_{2} \mathrm{TM}$ PyP (1:1) & 6.39 & 6.69 & 3.34 & 9.22 & 8.80 & 4.77 \\
\hline
\end{tabular}

a. Chemical shifts of $\mathrm{N}$-methyl protons were not clearly determined, because of the overlap of their peaks on the peaks of water. 


\section{Discussion}

Nucleotides interact with cationic water-soluble porphyrin, $\mathrm{H}_{2} \mathrm{TMPyP}$, along with an absorption spectral change at the Soret band as well as the upfield shifts of the ${ }^{1} \mathrm{H}$-NMR signals of the adenine and ribose protons. Comparing the formation constants of the molecular complexes in Table 1, one may notice that the molecular complex is stabilized by both electrostatic and hydrophobic interactions. The increased stability, compared with nucleotides and adenosine or adenine, can be calculated using

$$
\frac{\Delta \log K}{\log K_{N}}=\frac{\log K_{\mathrm{N}}-\log K_{\mathrm{A}}}{\log K_{\mathrm{N}}},
$$

where $\log K_{\mathrm{N}}$ and $\log K_{\mathrm{A}}$ denote the formation constants of $\mathrm{H}_{2} \mathrm{TMPyP}$ with nucleotides and adenosine or adenine. The calculated values are given as the contribution of electrostatic interaction for the stability of the molecular complex in Table 1, assuming both an additivity of the free energies of the electrostatic and the hydrophobic binding forces for the formation of a molecular complex and that the electrostatic interaction of adenosine or adenine with $\mathrm{H}_{2}$ TMPyP might be negligible. The remaining stability in molecular complex formation may come from a hydrophobic interaction. Stabilization of the molecular complexes concerns both hydrophobic and electrostatic interactions; their contributions to the formation of molecular complexes are 75 and $25 \%$, respectively. In addition, though the charge of sodium triphosphate $\left(\mathrm{HP}_{3} \mathrm{O}_{10}{ }^{4-}\right)$ is identical to that of $\mathrm{ATP}^{4-}$ at $\mathrm{pH} 6.8$, the interaction between triphosphate and $\mathrm{H}_{2}$ TMPyP is too weak for the formation constant to be determined. This result also shows that the electrostatic interaction is small compared with the hydrophobic interaction.

The coordination of magnesium, calcium or nickel to ATP and the protonation of phosphate groups do not decrease the stability of a molecular complex. Protonation to the adenine base, however, decreases the stability because of its interference with the hydrophobic interaction between the adenine base and the porphyrin plane. Furthermore, the molecular complexes of $\mathrm{H}_{2}$ TMPyP with ATP and adenosine were destabilized by the addition of ethanol. If the predominant bond between ATP and $\mathrm{H}_{2}$ TMPyP is either ion-pair formation or an electrostatic interaction, the molecular complex may be stabilized by the addition of ethanol, as expected from a Born equation for ion-pair formation, since the dielectric constant of an aqueous solution decreases upon the addition of ethanol. The molecular complex of adenosine-( $\left.\mathrm{H}_{2} \mathrm{TMPyP}\right)$ was more easily destabilized by the addition of ethanol, compared with ATP( $\mathrm{H}_{2}$ TMPyP $)$. This result is in agreement with the existence of an electrostatic interaction between ATP and $\mathrm{H}_{2}$ TMPyP. The effect of ethanol on a molecular complex formation shows the importance of

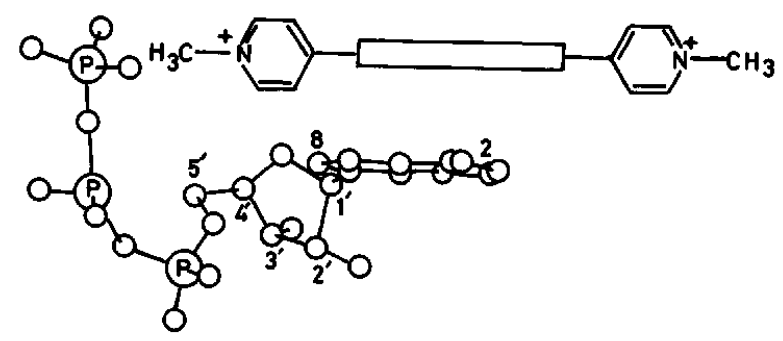

Fig. 5 Possible structure for the molecular complex of ATP with $\mathrm{H}_{2}$ TMPyP.

hydrophobic interaction.

One of the most important features concerning the conformation determining the existence of possible interaction is the relative orientation of the base and the phosphate group. Figure 5 shows a possible structure of the molecular complex of $\mathrm{H}_{2}$ TMPyP with ATP. The positively charged $\mathrm{N}$-methyl group interacts with the phosphate of the nucleotides through an electrostatic interaction; the porphyrin plane does the same with the adenine base through a hydrophobic interaction. Both the ${ }^{1} \mathrm{H}-\mathrm{NMR}$ signals for the adenine base protons $(\mathrm{H}-8$ and $\mathrm{H}-2$ ) and for the ribose proton of $\mathrm{H}^{-1} \mathbf{1}^{\prime}$ shift higher upfield through hydrophobic interactions. 5'-Monophosphate (AMP) does not bind much with $\mathrm{H}_{2} \mathrm{TMPyP}$, as does ATP or ADP. This may be due to the short distance between a negatively charged portion and the adenine base. In such a case, both the electrostatic and hydrophobic interactions do not work together well in the formation of $\operatorname{AMP}\left(\mathrm{H}_{2} \mathrm{TMPyP}\right)$.

The present study clearly suggests that a hydrophobic interaction (a $\pi-\pi$ interaction or stacking) between the adenine base and porphyrin plane is important, and that an electrostatic interaction enhances binding to an extent of $25 \%$ regarding the interaction between cationic water-soluble porphyrins and nucleotides. Schneider $e t$ al..$^{20}$ have recently reported on the electrostatic interaction between the positively charged Nmethyl group and the phosphate groups of DNA in terms resonance Raman spectroscopy; they suggested a similar structure (Fig. 5). The DNA binding specificity of a group of cationic porphyrins of manganese(II) with different positive charges has been examined using a DNase I footprinting methology; the specificity decreased in the order $\mathrm{Mn}(\mathrm{TMPyP})^{4+}>\mathrm{Mn}(\mathrm{TMPyP})^{3+}$ Mn(TMPyP $)^{2+}>\mathrm{Mn}\left(\mathrm{TMPyP}^{+}\right)^{5}$ The result regarding DNA is also in good agreement with the present results: the electrostatic interaction is small, but not negligible, and the hydrophobic interaction is predominant in positively charged porphyrins and nucleotides.

We are thankful for support through a Grant-in-Aid for Scientific Research No. 01470030 from the Ministry of Education; we also appreciate support from the Asahi Glass research foundation.

This study was presented at the 50th symposium of The 
Japan Society for Analytical Chemistry in Matue on July 3 $5,1989$.

\section{Reference}

1. R. J. Fiel, J. Biomol. Struct. Dynamics, 6, 1259 (1989).

2. M. J. Carvlin and R. J. Fiel, Nucleic Acids Res., 11, 6121 (1983).

3. M. J. Carvlin, E. Mark and R. J. Fiel, J. C. Howard, Nucleic Acids Res., 11, 6141 (1983).

4. R. F. Pasternack, E. J. Gibbs and J. J. Villafranca, Biochemistry, 22, 2406 (1983).

5. S. D. Bromely, B. W. Ward and J. C. Dabrowiak, Nucleic Acids Res., 14, 9133 (1986).

6. L. G. Marzilli, D. L. Banville, G. Zon and W. D. Wilson, J. Am. Chem. Soc., 108, 4188 (1986).

7. B. Ward, A. Skorobogaty and J. C. Dabrowiak, Biochemistry, 25, 7827, (1986).

8. J. A. Strickland, D. L. Banville, W. D. Wilson and L. G. Marzilli, Inorg. Chem., 26, 3398 (1987).

9. J. A. Strickland, L. G. Marzilli, K. M. Gay and W. D. Wilson, Biochemistry, 27, 8870, (1988).

10. R. F. Pasternack, E. J. Gibbs, A. Gaudemer, A. Antebi, S. Bassner, L. De poy, D. H. Turner, A. Wiliams, F.
Laplace, M. H. Lansard, C. Merienne and M. PerreeFauveret, J. Am. Chem. Soc., 107, 8179 (1985).

11. K. G. Ford, L. H. Pearl and Neidle, Nucleic Acids Res., 15, 6553 (1987).

12. K. H. Scheller, F. Hofstetter, P. R. Mitchell, B. Prijis and H. Sigel, J. Am. Chem. Soc., 103, 247 (1981).

13. A. Shamim and P. Hambright, Inorg. Chem., 19, 564 (1980).

14. R. W. Gellert and R. Bau, "Metal lons in Biological Systems”, ed. H. Sigel, Vol. 7, p. 1, Marcel Dekker, New York, 1979.

15. R. B. Martin and Y. H. Mariam, "Metal Ions in Biological Systems", ed. H. Sigel, Vol. 8, p. 57, Marcel Dekker, New York, 1979.

16. H. Sigel, J. Inorg. Nucl. Chem., 39, 1903 (1977).

17. A. E. Martell and R. M. Smith, "Critical Stability Constants", Vol. 2., Plenum, New York, 1975.

18. H. Sigel, R. Tribolet, R. Malini-Balakrishnan and R. B. Martin, Inog. Chem., 26, 2149 (1987).

19. A. Corsini and O. Herrmann, Talanta, 33, 335 (1986).

20. J. H S. Schneider, J. Odo and K. Nakamoto, Nucl. Acids Res., 16, 10323 (1988).

(Received March 14, 1990)

(Accepted July, 5, 1990) 